\title{
H1N1 influenza: Does chest radiograph have a role in predicting prognosis?
}

\author{
Sripathi $\mathbf{S}^{1}$, Srivastava $\mathbf{R}^{2}$ \\ ${ }^{1}$ Dr. Smiti Sripathi, Professor, Dept of Radiodiagnosis, Kasturba Medical College, Manipal University, Manipal, ${ }^{2}$ Dr \\ Rajendra Srivastava, Professor, Dept. of Radiodiagnosis, Shri Guru Ram Rai Institute of Medical and Health Sciences, \\ Dehradun, Uttarakhand, India
}

Address for correspondence: Dr. Smiti Sripathi, Email: smitis11@ hotmail.com

\begin{abstract}
Aims and Objectives: To assess pattern and distribution of chest ray findings in proven case of H1N1 \& to evaluate sequential radiographs to assess progression/ resolution of disease. Material and Methods: Patients presenting to a tertiary care hospital in coastal Karnataka, India, from May 2009 to Feb 2011, who tested positive for H1N1 virus with real time PCR test and underwent chest X ray were included in the study. The pattern and distribution of findings and extent of involvement was studied in the initial chest radiograph. Sequential radiographs were studied for progression of disease. Results: The age of patients ranged from 1 to 65 years with 11 (31.5\%) patients in pediatric age group, two patients above 60 years and rest were middle age adults $(62.8 \%)$. Out of 39 patients, four patients had a normal chest radiograph. In the remaining 35 patients, commonest finding was consolidation $(77.1 \%)$ followed by ground glass opacity (68.6\%). Thirty patients had involvement of both lungs at presentation out of which 17 improved, 12 patients expired and one was discharged on request. Conclusion: Patients with bilateral multi zonal involvement at presentation deteriorated faster and had an adverse outcome whereas patients with single zone or unilateral involvement had a better outcome. Consolidation and ground glass opacities, especially if bilateral and multi zonal predicted adverse outcome. Chest radiograph can play an important role in assessing pattern and distribution of findings and may help in predicting prognosis.
\end{abstract}

Keywords: H1N1, Chest x ray, pattern

\section{Introduction}

The influenza virus has been the cause of recurrent epidemics and global pandemics in human population since the $16^{\text {th }}$ century [1]. The current pandemic of a novel influenza A (H1N1) virus started in Mexico in March 2009 and startled the world. The World Health Organization declared global influenza pandemic in June 2009 [2]. First case of novel influenza A (H1N1) was reported from India in May 2009 [3]. A total of 190,990 persons were tested for influenza A H1N1 in various Indian laboratories from May 2009 up to $3^{\text {rd }}$ October 2010 out of which there were 44,687 (23.3\%) lab confirmed cases with a death toll of 2574 patients [4]. We are publishing this study as it highlights the pattern and distribution of radiographic findings in

Manuscript received: $30^{\text {th }}$ November 2016

Reviewed: $07^{\text {th }}$ December 2016

Author Corrected: $14^{\text {th }}$ December 2016

Accepted for Publication: 20 $0^{\text {th }}$ December 2016 proven cases of $\mathrm{H} 1 \mathrm{~N} 1$ virus with follow-up sequential radiographs to assess progression of disease.

\section{Objectives}

1. To assess pattern and distribution of chest ray findings in proven case of H1N1 by real time PCR.

2. To evaluate sequential radiographs to assess progression/ resolution of disease.

\section{Material and Methods}

This is a retrospective observational study wherein patients presenting to a tertiary care hospital in coastal Karnataka, from May 2009 to Feb 2011, who tested positive for H1N1 virus with real time PCR test were included. Approval from Institutional ethical committee was obtained for the study. 
Inclusion criteria: Patients who tested positive for H1N1 virus with real time PCR test and underwent Chest radiograph were included.

Exclusion criteria: Patients who did not test positive for H1N1 virus with real time PCR test and/or did not undergo chest radiograph were excluded.

A total of 42 patients tested positive for H1N1 virus by PCR test out of which Chest radiograph was done in 39 patients and these patients were included in the study.

Three patients did not undergo a chest X-ray as they did not have respiratory symptoms and were excluded from the study.

The clinical findings at presentation and duration of symptoms at the time of presentation were recorded. The Chest radiographic findings in these 39 patients were assessed by two experienced radiologists (both with more than 8 years of experience). The radiographic findings which were considered for evaluation included: consolidation, ground glass opacity, interstitial or nodular opacities, pleural effusion and lymphadenopathy. The distribution of the disease was examined with respect to the side involved (left, right or bilateral), zonal distribution (upper, middle and lower zone) and zonal predominance. A consensus was reached after evaluating pattern and the distribution of disease and findings were recorded using SPSS statistical software version 11.5 .

Sequential radiographs were done in patients with progressive clinical signs and assessed for progression/resolution of the disease; however pattern of distribution and extent of involvement was studied only in the initial chest radiograph. CT scan of Thorax was not done in any of the cases in our study.

\section{Results}

Demography: The age of patients ranged from 1 to 65 years with 11 (31.5\%) patients in pediatric age group ,two patients above 60 years and rest were middle age adults (62.8\%). All pediatric patients were less than seven years of age; where the age of adult patients ranged from 23 to 55 years. Males (20) were more than females (15) with a ratio of 4:3.

Vulnerable group (60\%) was defined as extremes of age which included pediatric $(31.4 \%)$ and geriatric age group patients $(5.8 \%)$, pregnant $(8.6 \%)$ and patients with underlying chronic diseases such as diabetes mellitus, chronic respiratory, cardiac disease or chronic renal failure $(14.3 \%)$.

Clinical findings: The most common symptom on presentation was fever $(97.1 \%)$ followed by cough $(88.6 \%)$ and dyspnea $(77.1 \%)$. Ten patients had sore throat $(68.6 \%)$ and three patients presented with hemoptysis. Crepitation was the most common finding on auscultation $(68.6 \%)$ and in $14 \%$ cases there was a history of contact with a patient with $\mathrm{H} 1 \mathrm{~N} 1$ infection.

In 33 patients, duration of symptoms prior to admission ranged from 1 to 15 days with a median of seven days whereas in two cases the duration of symptoms was not available. Duration of hospitalization period was in range of 1-30 days with a median of 6 days. The longest hospitalization was for a woman in her third trimester of pregnancy who was admitted for 30 days.

Twenty two $(62.9 \%)$ patients recovered from the disease and were discharged, $12(34.3 \%)$ patients had adverse outcome (expired) whereas one patient was discharged on request. Patients with bilateral multizonal involvement and adverse outcome had a shorter duration of symptoms before admission (1-10 days with median of 6.5 days) as compared to patients who improved (1-14 days with a median of 7 days).

The duration of hospitalization period in patients with adverse outcome (expired) was significantly less, 1-14 days with median of 4.5 days as compared to patients who improved, 1-30 days with median of 8 days.

Radiographic findings: Out of 39 patients, four patients had a normal chest radiograph. In the remaining 35 patients the pattern of radiographic findings were assessed which are summarized in Table 1. The commonest radiographic finding was consolidation $(77.1 \%)$ followed by ground glass opacity $(68.6 \%)$. Other findings included interstitial thickening, nodules and pleural effusion. 
Table-1: Pattern of Radiographic findings on CXR

\begin{tabular}{|c|c|}
\hline Radiographic findings & Number of cases (percentage) \\
\hline Consolidation & $27(77.1 \%)$ \\
\hline Ground glass opacity & $24(68.6 \%)$ \\
\hline Isolated ground glass opacity & $6(17.1 \%)$ \\
\hline Isolated consolidation & $9(25.7 \%)$ \\
\hline Both consolidation and ground glass opacity & $18(51.4 \%)$ \\
\hline Interstitial pattern & $2(5.7 \%)$ \\
\hline Nodular pattern & $2(5.7 \%)$ \\
\hline Pleural effusion & $3(8.6 \%)$ \\
\hline Prominent hila (hilar lymphadenopathy) & $15(42.9 \%)$ \\
\hline Pneumothorax & $1($ patient expired) \\
\hline
\end{tabular}

The distributions of radiographic findings are summarized in Table 2. Out of 35 patients, five (14.3\%) had unilateral involvement, $30(85.7 \%)$ involved both lung fields with nine having predominantly right and three left side involvement. In $18(51.4 \%)$ cases both lungs were involved almost equally. Overall a total of $11(31.4 \%)$ patients had right sided dominance and six (17.1\%) patients had left sided dominance while 18 (51.4\%) patients had equal involvement on both the sides.

Table-2: Distribution of Radiographic findings on chest radiograph

\begin{tabular}{|c|c|}
\hline Sides involved: & \\
\hline Unilateral & $5(14.3 \%), 2$ right, 3 left \\
\hline Bilateral & $\begin{array}{c}30(85.7 \%) \text {, predominance } 9 \text { right, } 3 \text { left, } 18(51.4 \%) \\
\text { bilateral equal involvement }\end{array}$ \\
\hline Predominance of side involved & $11(31.4 \%)$ right, $6(17.1 \%)$ left \\
\hline \multicolumn{2}{|l|}{ Zonal predominance: } \\
\hline All zones & $6(17.1 \%)$ \\
\hline Mid and lower zones & $18(51.4 \%)$ \\
\hline Mid zone & $4(11.4 \%)$ \\
\hline Lower zone & $6(17.1 \%)$ \\
\hline Upper and mid zone & $1(2.9 \%)$ \\
\hline Mid zone, lower zone or combined mid and lower zone & $28(80 \%)$ \\
\hline \multicolumn{2}{|l|}{ Central and peripheral distribution: } \\
\hline Central predominance & $14(40 \%)$ \\
\hline Peripheral predominance & $9(25.7 \%)$ \\
\hline Almost equal involvement & $12(34.3 \%)$ \\
\hline
\end{tabular}

Zonal distribution of radiographic findings was observed followed by study of zones affected more severely and distribution of pathology in terms of central or peripheral predominance.

30 patients had involvement of both lung fields at presentation out of which 17 improved, 12 patients expired and one was discharged on request. In five cases with unilateral or single zone involvement, there was no casualty.

In our series mortality was more in cases with peripheral involvement of lung fields. Mortality in different groups are as follows: four out of nine with peripheral lung involvement (44.4\%), in patients with involvement of both central and peripheral region mortality was $41.7 \%$ (5 out of 12), as compared to patients with central predominance, 3 out of 14 $(21.4 \%)$.

There was no significant difference in outcome in patients with and without pleural effusion. 


\section{Discussion}

Radiographic findings in H1N1 influenza patients have been published in literature from different parts of the world ever since the pandemic in 2009.

Bakhshayeshkaram et al [5] described imaging findings in H1N1 influenza patients in his study on patients in Iran. The most common chest radiographic finding was consolidation in lower zones. The patients who were sick and admitted to ICU had involvement of two or more lung zones. CT scan was done in only 10 patients who showed ground glass opacities as the most common pattern followed by consolidation.

Perez Pallida [6] described bilateral basal alveolar opacities as the most common radiographic finding in his study on 18 cases of swine flu.

Bilateral and multizonal opacities were common radiographic presentations, seen in about $60-70 \%$ of H1N1 patients by Aviram $G$ et al [7] who observed that the patients with adverse outcomes had four or more zonal involvement and bilateral peripheral distribution occurred with higher frequency compared with patients with good outcomes: multizonal opacities: $60 \%$ vs $6 \%, P=.01$; bilateral peripheral opacities: $60 \%$ vs $15 \%, P=.049$ [6]. Our study also showed similar outcome in patients with bilateral multiple zone involvement: out of the 15 patients having involvement of all the zones, nine $(60 \%)$ expired whereas all five patients with unilateral involvement recovered.

The majority of chest radiograph findings in a study by Choi et al [8] in pediatric population included prominent peribronchial markings and consolidation (85-96\%), and ground-glass opacities without consolidation in a minority (8\%) of patients. Bilateral involvement with lower zone predominance was the usual feature. We noticed consolidation in $73 \%$, ground glass opacity in 55\% and peribronchial thickening in only $9 \%$ of patients. Our series showed significant central distribution pattern of radiographic findings in children $(81.8 \%)$ compared to adult population in which central distribution was seen in only $46 \%$. Abbo L et al [9] didn't find any such dominant distribution in their study.

We documented increased mortality in patients with peripheral involvement (44.4\%) and with involvement of both central and peripheral region $(41.7 \%)$ as compared to patients with central predominance (21.4\%). Aviram G et al also found poor prognosis in patients with four or more lung zone involvement with peripheral distribution.

Pleural effusion was noticed less frequently in our series (8.6\%) as compared to that by McEwen et al [2] who found it in $50 \%$ of his patients.

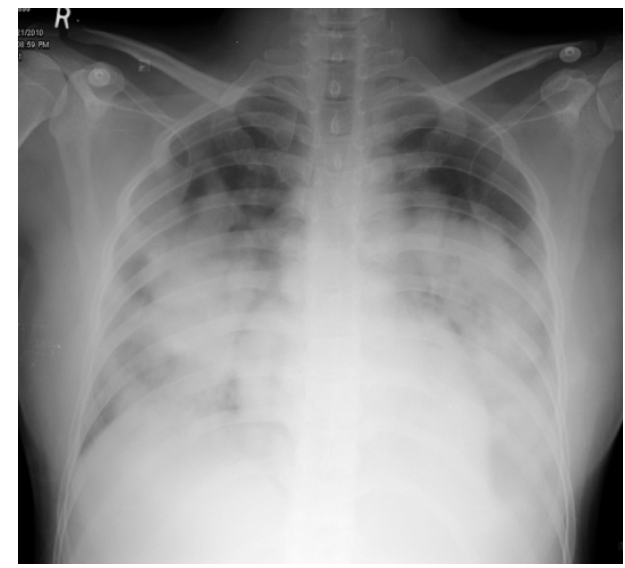

Fig 1: A 30 year old female presented with complaint of fe Chest ver for 3 days and severe breathlessness for 2 days. Chest radiograph shows bilateral mid and lower zone consolidation with left pleural effusion.

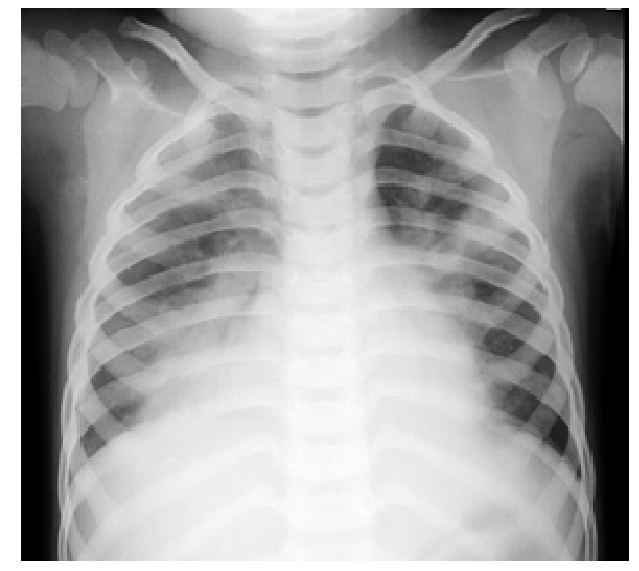

Fig 2: A three year old girl presented with history of fever and cough since 5 days and breathlessness since 1 day. Chest radiograph shows consolidation and ground glass opacities in mid and lower zone on both sides. 


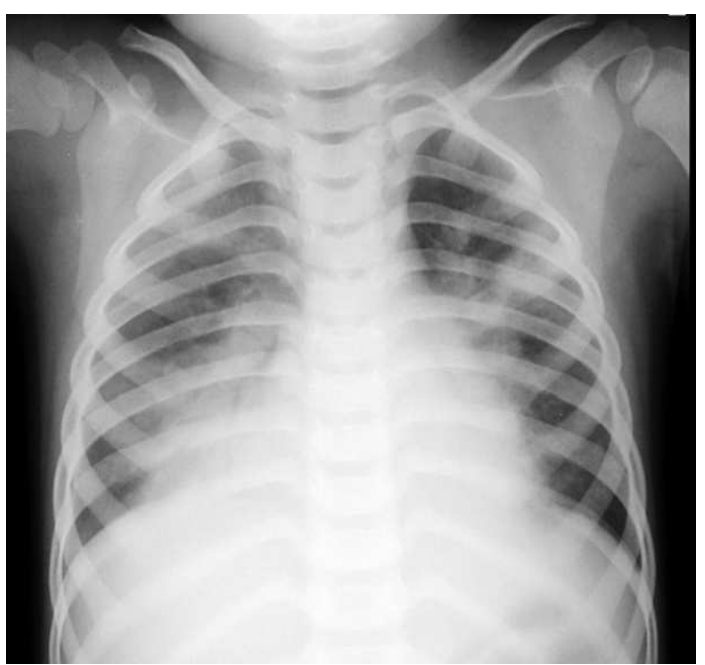

Fig 3: A two year old child came with complaint of fever and cough since 3 days and severe breathlessness for one day. CXR PA view shows consolidation in mid and lower zones on right and in upper lobe.

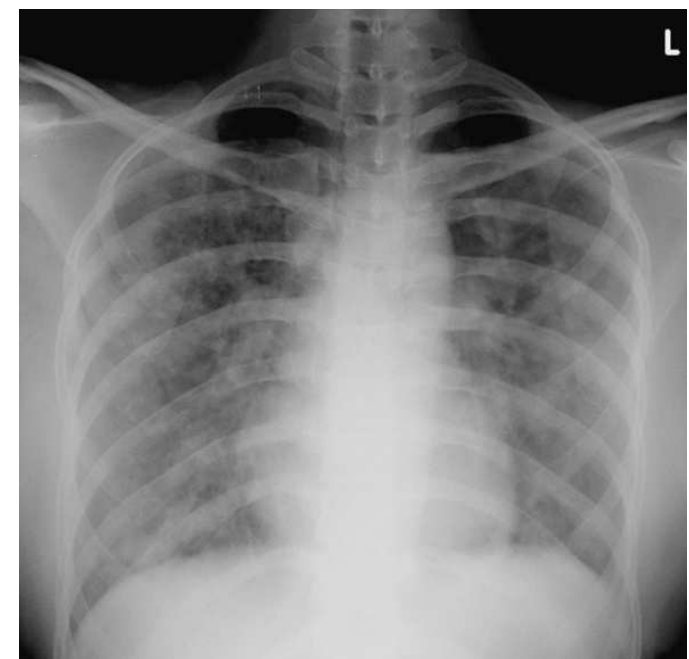

Fig 4: A 35 year old female presented with fever and breathlessness for 4 days. Chest radiograph showed diffuse interstitial pattern in both lungs.

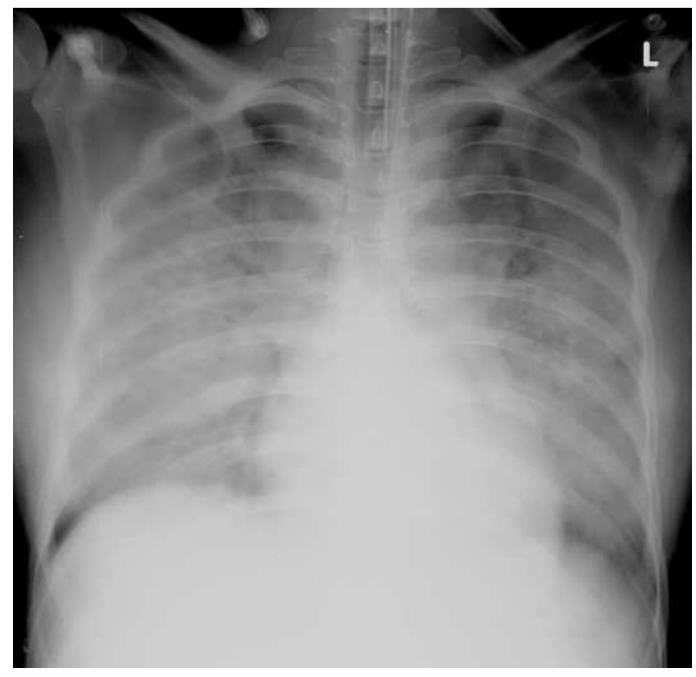

Fig 5: A 28 year old female presented with fever for a week and dry cough and dyspnea for 2 days. CXR PA view shows diffuse bilateral multizonal ground glass opacity and air space opacities

Nicolini et al [10] studied chest radiographs and CT chest findings in his patients in Italy and found that predominant findings on chest $\mathrm{CT}$ in the patients at presentation were unilateral or bilateral multifocal ground glass opacities which were seen in $84.5 \%$ of his patients.

Multifocal bilateral opacities and CXR score were strictly correlated with the severity of the illness. Nizar et al [11] concluded from their study that chest radiographs in patients with suspected H1N1 should only be obtained if there is a cough or sore throat. Other symptoms associated with $\mathrm{H} 1 \mathrm{~N} 1 \mathrm{do}$ not warrant a chest radiograph unless absolutely necessary.

In the study by Aviram $\mathrm{G}$ et al, the median time from admission to chest radiography was 24 hours and median time between the beginning of symptoms and initial chest radiograph was 72 hours. Overall, the median hospitalization period was three days [7]. When comparing it with our study, we found that patients with bilateral, multizonal involvement and 
adverse outcome had shorter duration of symptoms at presentation (median 6.5days) as compared to patients who improved (median 7 days).

Duration of hospitalization period was significantly less in these patients (median 4.5 days) as compared to patients who recovered (median 8 days). These findings suggest that patients with bilateral multi zonal involvement and adverse outcome had more severe disease at presentation and therefore deteriorated fast.

Duration of symptoms before presenting to hospital was more in our study especially in patients with adverse outcome as compared to study of Aviram G et al where it was only 72 hours.

This may be because of lack of awareness about this disease in our population as well as lack of basic healthcare facilities as compared to the west and likely explains the reason of more percentage of cases having adverse outcome.

When compared to study done by McEwen et al [2] , inspite of having more number of positive radiographs in our study, the percentage of patients requiring intensive care was almost same(,50\% in their study and $48.6 \%$ in our study). The increase in number of positive radiographic findings in our series could be attributed to delay in reaching the hospital after the onset of first symptoms.

Table 3 shows comparison of, distribution and adverse outcomes in present study with other studies. Comparison of pattern and distribution of findings in present study with other studies has been summarized in Table 4.

Table-3: Comparison of distribution and adverse outcomes in present study with other studies.

\begin{tabular}{|c|c|c|c|c|c|c|}
\hline Authors & $\begin{array}{l}\text { Total } \\
\text { number of } \\
\text { cases with } \\
\text { abnormal } \\
\text { CXR }\end{array}$ & $\begin{array}{l}\text { Bilatera } \\
\text { l }\end{array}$ & Unilateral & $\begin{array}{l}\text { Zonal } \\
\text { dominan } \\
\text { ce }\end{array}$ & $\begin{array}{l}\text { Distribution } \\
\text { central/peripheral }\end{array}$ & $\begin{array}{l}\text { Adverse } \\
\text { outcome } \\
\text { (deaths) }\end{array}$ \\
\hline McEwen RE [2] & $12(23.1 \%)$ & $6(50 \%)$ & $6(3 \mathrm{rt}, 3 \mathrm{lt})$ & basal & Not noted & $1(8.3 \%)$ \\
\hline Abbo[9] L & 39 & $23(59 \%)$ & $16(41 \%)$ & $\begin{array}{l}21(54 \%) \\
\mathrm{lz}\end{array}$ & None & $6(4 \%)$ \\
\hline $\begin{array}{l}\text { Min Jeong Choi } \\
\text { [8] (pediatrics) }\end{array}$ & $26(6 \%)$ & $\begin{array}{l}19( \\
73 \%)\end{array}$ & $7(27 \%)$ & $\begin{array}{l}1 \mathrm{z}, 22 \\
(85 \%)\end{array}$ & Not noted & 0 (no deaths) \\
\hline Aviram I[7] & $39(40 \%)$ & $\begin{array}{l}24 \\
(62 \%)\end{array}$ & $15(38 \%)$ & $\begin{array}{l}\mathrm{mz} 26 \\
(66.7 \%) \\
\text { right, } 24 \\
(62 \%) \text { left } \\
\end{array}$ & peri $77 \%$ & $4(10.2 \%)$ \\
\hline $\begin{array}{l}\text { Present study( } \\
\text { Total) }\end{array}$ & $35(83.3 \%)$ & $\begin{array}{l}30(85.7 \\
\%)\end{array}$ & $5(14 . .3 \%)$ & $\begin{array}{l}18(51.4 \% \\
) \mathrm{mz}, \mathrm{lz}\end{array}$ & $\begin{array}{l}14(40 \%) \text { cen, } \\
9(25.7 \%) \text { peri, }\end{array}$ & $12(34.2 \%)$ \\
\hline $\begin{array}{l}\text { Abbo L[9] ( } \\
\text { pediatric) }\end{array}$ & 19 & $15(81 \%)$ & $4(19 \%)$ & $\operatorname{lz~8(42\% )}$ & None & Not mentioned \\
\hline $\begin{array}{l}\text { Present study } \\
\text { (pediatric) }\end{array}$ & 11 & $\begin{array}{l}9(81.8 \% \\
)\end{array}$ & $2(18.2 \%)$ & $\begin{array}{l}5(45.5 \%) \\
\mathrm{mz} \text { and } \mathrm{lz}\end{array}$ & cen $9(81.8 \%)$ & $2(18.2 \%)$ \\
\hline Abbo L [9]( adult) & 39 & $23(59 \%)$ & $16(41 \%)$ & $\begin{array}{l}\mathrm{lz} \\
21(54 \%)\end{array}$ & $\operatorname{cen} 6(15 \%)$ & Not mentioned \\
\hline $\begin{array}{l}\text { Present study } \\
\text { adult }\end{array}$ & 24 & $\begin{array}{l}21(87.5 \\
\%)\end{array}$ & $3(12.5 \%)$ & $\begin{array}{l}13(54.2 \% \\
) \mathrm{mz} \text { and } \\
\mathrm{lz}\end{array}$ & Both 11(45.8\%) & $10(41.7 \%)$ \\
\hline
\end{tabular}

Uz-upper zone, mz-mid zone, lz-lower zone, dopr-discharged on patient request, cen-central, per-peripheral, rtright, lt-left 
Table-4 Comparison of radiographic patterns and distribution in present study with other studies

\begin{tabular}{|c|c|c|c|c|c|c|c|}
\hline Study & Consolidation & $\begin{array}{l}\text { Ground } \\
\text { glass } \\
\text { opacity }\end{array}$ & Interstitial & Nodule & $\begin{array}{l}\text { Pleural. } \\
\text { effusion }\end{array}$ & Lymphadenopathy & $\begin{array}{l}\text { bilateral } \\
\text { multizonal } \\
\text { involvement }\end{array}$ \\
\hline $\begin{array}{l}\text { McEwen RE } \\
{[2]}\end{array}$ & $12(100 \%)$ & $\begin{array}{l}\text { Not } \\
\text { noted }\end{array}$ & nil & $\begin{array}{l}\text { Not } \\
\text { noted }\end{array}$ & $6(50 \%)$ & Not noted & $3(25 \%)$ \\
\hline $\begin{array}{l}\text { Min Jeong } \\
\text { Choi } \\
{[8] \text { (pediatric) }}\end{array}$ & $22(85 \%)$ & $2(8 \%)$ & $25(96 \%)$ & $\begin{array}{l}\text { Not } \\
\text { noted }\end{array}$ & $\begin{array}{l}11 \\
(42 \%)\end{array}$ & Not noted & Not noted \\
\hline $\begin{array}{l}\text { Present } \\
\text { study( total) }\end{array}$ & $27(77.1 \%)$ & $\begin{array}{l}24 \\
(68.6 \%)\end{array}$ & $2(5.7 \%)$ & $\begin{array}{l}2 \\
(5.7 \%)\end{array}$ & $\begin{array}{l}3 \\
(8.6 \%)\end{array}$ & $15(42.9 \%)$ & $17(48.6 \%)$ \\
\hline Abbo L[9] & $32(82 \%)$ & 9 & 4 & 2 & 1 & 1 & Not noted \\
\hline Aviram [7] & $23(59 \%)$ & $\begin{array}{l}27 \\
(69 \%)\end{array}$ & $\begin{array}{l}\text { Not } \\
\text { mentioned }\end{array}$ & $\begin{array}{l}11 \\
(28 \%)\end{array}$ & $3(8 \%)$ & not mentioned & $72 \%$ \\
\hline $\begin{array}{l}\text { Abbo L } \\
{[9] \text { (pediatric) }}\end{array}$ & $12(29 \%)$ & $1(2 \%)$ & 0 & 0 & 0 & $1(2 \%)$ & Not noted \\
\hline $\begin{array}{l}\text { Present } \\
\text { study( } \\
\text { pediatric) }\end{array}$ & $8(72.7 \%)$ & $\begin{array}{l}6 \\
(54.5 \%)\end{array}$ & $1(9.1 \%)$ & $\begin{array}{l}1 \\
(9.1 \%)\end{array}$ & $\begin{array}{l}1 \\
(9.1 \%)\end{array}$ & $4(36.4 \%)$ & $3(27.3 \%)$ \\
\hline $\begin{array}{ll}\text { Abbo } & \text { L } \\
\text { [9]adult) } & \end{array}$ & $20(25 \%)$ & $8(10 \%)$ & $4(5 \%)$ & $2(3 \%)$ & $1(1 \%)$ & 0 & Not noted \\
\hline $\begin{array}{l}\text { Present } \\
\text { study (adult) }\end{array}$ & $19(79.2 \%)$ & $\begin{array}{l}18 \\
(75.0 \%)\end{array}$ & $1(4.2 \%)$ & $\begin{array}{l}1 \\
(4.2 \%)\end{array}$ & $\begin{array}{l}2 \\
(8.3 \%)\end{array}$ & $11(45.8 \%)$ & $14(58.3 \%)$ \\
\hline
\end{tabular}

Limitation of our study included small study population, retrospective nature of analysis and one patient being lost to follow up. In the recent times studies have been done evaluating CT findings in H1N1 infection which was not done in our study due to a different study design.

\section{Conclusion}

Patients with bilateral multi zonal involvement at presentation deteriorated fast and had an adverse outcome whereas patients with single zone or unilateral involvement had a better outcome.

- Consolidation and ground glass opacities, especially if is bilateral and multizonal predicted adverse outcome.

- Chest radiograph can play an important role in assessing pattern and distribution of findings and may help in predicting prognosis. Chest radiograph can play an important role in assessing pattern and distribution of findings and may help in predicting prognosis.

Funding: Nil, Conflict of interest: None initiated, Permission from IRB: Yes

\section{References}

1. CD alert (webpage on the internet). India: Monthly Newsletter of National Institute of Communicable Diseases, Directorate General of Health Services, Government of India, [cited March-April 09, vol12: no8]. Available from: http://www.india.gov.in/allimpfrms/alldocs/12416.pdf

2. McEwen RE, Scriven JE, Green CA, Bailey MS, Banerjee AK. Chest radiography findings in adults with pandemic H1N1 2009 influenza. Br J Radiol. 2010 Jun;83(990):499-504. doi: 10.1259/bjr/24252450.

3. Public Health Foundation of India, (homepage on internet). India: Novel Influenza $\mathrm{A}(\mathrm{H} 1 \mathrm{~N} 1)$, General information for health care workers. [Cited 2009]. Available from www.phfi.org/h1n1flu/index.html

4. Office of the Director, Emergency Medical Relief (webpage on internet). India: Directorate General of Health Services, Government of India, New Delhi; [cited Aug 2010]. Available 
fromhttp://mohfwh1n1.nic.in/documents/PDF/Situation alUpdatesArchives/august2010/Situational Updates on 29.08.2010.pdf.

5. Mehrdad Bakhshayeshkaram, Bahareh Saidi , Payam Tabarsi , Soheila Zahirifard

Mishka Ghofrani. Imaging Findings in Patients With H1N1 Influenza A Infection : Iranian journal of Radiology, 2011 ,8(4), 230-234.

6. Perez-Padilla R, de la Rosa-Zamboni D, Ponce de Leon S, Hernandez, M, Quinones-Falconi F, Bautista E, et al. Pneumonia and respiratory failure from swineorigin influenza A (H1N1) in Mexico. N Engl J Med. 2009; 361(7):680-9

7. Aviram $G$ et al. H1N1 Influenza: Initial Chest Radiographic Findings in Helping Predict Patient Outcome. Radiology: 2010; 255:252-259.
8. Choi J M, Lee Y S S, Lee J Y, Lee K S. Novel Influenza A (H1N1) Virus Infection in Children: Chest Radiographic and CT Evaluation. Korean J Radiol 2010;11:656-664

9. L Abbo L, Quartin A, Morris M I, Saigal G, ArizaHeredia E, P Mariani, Rodriguez O, et al. Pulmonary imaging of pandemic influenza H1N1 infection: Relationship between clinical presentation and disease burden on chest radiography and CT. The British Journal of Radiology, 2010,(83) 645-651

10. Nicolini A, Ferrera L, Rao F, Senarega R, FerrariBravo M. Chest radiological findings of influenza A H1N1 pneumonia.Rev Port Pneumol. 2012;18(3):120-7.

11. Nizar A. Al-Nakshabandi. Determining symptoms for chest radiographs in patients with swine flu (H1N1), Pol J Radiol. 2011; 76(4): 45-48.

\section{How to cite this article?}

Sripathi S , Srivastava R. H1N1 influenza: Does chest radiograph have a role in predicting prognosis?. Int J Med Res Rev 2016;4(12):2156-2163.doi:10.17511 /ijmrr. 2016.i12.13. 